\title{
NAVIGATING A FRACTAL WORLD: IBN AL-'ARABĪ, CIVILISATIONAL RENEWAL, AND THE NEW SCIENCES
}

\author{
Eric Winkel ${ }^{*}$
}

\begin{abstract}
After surveying visions of the future, this article engages some of the most interesting conceptualisations coming from the 'new sciences' and resonating with the perspective of civilisational renewal. The focus is on the environment, as the most accessible point of departure for visions of the future, and 'transition', as the best description of where we are. From here, the language of Islamic civilisational renewal is brought out to both deepen and sharpen the contemporary discourse.
\end{abstract}

\section{Introduction}

Sufis have always loved stories of the miraculous. Stories about Dhū 'l-Nūn al-Mișrī (d. 859) and Mullā Nașr al-Dīn (fl. 13th cent.), and especially of the Prophets, give sustenance to people who do not, or do not want to, believe this unmiraculous world of competition, selfishness, isolation and fragmentation is all there is. A mechanistic science in the West taught for three centuries that we live in such an unmiraculous, dead world. But in the last three decades, a very different picture is coming into focus. A new science is emerging which talks of connectedness (and quantum entanglement), of the robustness provided by diversity in complex systems, of the self-organisation of dissipative systems, of the inner coherency of fractals that are the 'fingerprint of God', and of impossible facts in the quantum world, where, for example, one thing occupies two spaces (quantum superposition). Whether recognised or not, whether one is actively involved or passively receptive, these strange ideas of the new science permeate human society and create a new vocabulary, language, metaphor. In the same way the world changed when the automobile entered, or the telephone, or the phonograph, or the internet, ideas from the new science change our language, and thereby change, and expand the limits of, our world.

The last three decades also coincide, not coincidentally, with the massive increase in interest and writing about Ibn al- 'Arabī (d. 1240). Here in his Futūhàt

* Eric Winkel is Principal Research Fellow at IAIS Malaysia.

ICR 2.3 Produced and distributed by Pluto Journals ICR.plutojournals.org 
al-makkiyyah ('Mekkan Openings') we find worlds far beyond that described by the 'binding intellect'. He talks about worlds where one thing is in two places, where an effect occurs without cause (Aharonov-Bohm effect), and where ants are intelligent (swarm intelligence). Hakim Bey anticipates that Ibn al-'Arabī "might prove a goldmine to Quantum Theorists, but the 'mingling of two oceans' conjured up by such an imagined confrontation would involve decades of hard labour to grasp and contain - and so I leave it to someone else to follow up". ${ }^{1}$

When scientists started talking about these things, people like Fritjof Capra, Frank Pirsig, and Ken Wilber started finding shared vocabularies with ancient wisdom, Heraclitus, and mysticism. If we as Muslim scholars are to contribute toward a civilisational renewal, we will have to speak in a language that is shared with a world that has been changed by new science. Fortuitously, we have in writings like the Futūhāt languages and metaphors that speak to this new world.

Computers, high energy, instruments that extend the senses (e.g., microscopes, telescopes), and new perspectives and paradigm shifts have opened up a 'new world' for science. My hope is that the metaphors and understandings of the new science will be evocative for a contemporary Muslim worldview, and that the descriptions of discoveries in the new science will call out from members of an Islamic civilisation a response. My suggestion is that a language that is able to understand and integrate these discoveries, and play them back and forth at a civilisational level, already exists in writings like the Futūhăt. Its language was developed to describe discoveries at a level beyond the bounded intellect, and to describe worlds accessed through alternative paths.

These paths and worlds include: the dream accessing the dream world; the imagination accessing the imaginal world; the metaphor accessing the inward spirit linked to the outward matter; the heart alternating with the fluctuation of the universe in every breath; and faith in the Unseen accessing the knowledge divinely provided to the messengers and prophets. Arabic words for the above are ru'yā, khayāl, i'tibār, qalb, and $\bar{m} \bar{a} n$ in risālah.

Today, Muslim societies are poorly prepared to contribute to the new science. They are also poorly prepared to speak with and engage others at a civilisational level. The enterprise of applying the higher goals of Islam, the maqāsid, has been dormant for centuries, allowing those who are hostile to Islam to portray "both the Qur'ān and Islamic jurisprudence as primitive in concept, irrelevant to any framework of justice, and focused entirely on superficial do's and don'ts without any higher purpose or coherent meaning". ${ }^{2}$ The 'Salafi' movement is an explicit attempt to reject the higher goals of Islam by erasing twelve centuries of Islamic development.

The Salafi response to the problem of making Islam relevant in the modern world is to proclaim, 'Islam is simple', and to reduce religious consciousness to a calculus of ritual 
obligations, external symbols of group identity (such as modern 'Islamic' dress), and political doctrines that promote cultural and creedal exclusivism. ${ }^{3}$

It is precisely to make Islamic civilisation once again relevant to justice globally, by renewing our understanding and application of its coherent meaning, that Islam Hadhari was conceived.

The need to renew is perennial. Opposition to renewal is also perennial. Ibn al- 'Arabì speaks of the legal scholars who are "congealed onto the outward". It seems clear that in order to engage the new science, we must re-engage the Islamic heritage, which functions fully at a comprehensive level of seen and unseen, outward and inward, literal and symbolic. The mechanistic science of the last 300 years is being replaced by a new science. The mechanistic science was suited to a 'binding intellect' that functions only at the level of seen, outward, and literal. A new perspective is opened up by computers, high energy, and paradigm shifts. If we are to engage it, the fully functioning, comprehensive nature of the Islamic heritage, which includes the unseen, inward, and symbolic, must be rediscovered. ${ }^{4}$

\section{Opening up to a New World}

Gaston Julia, born in Sidi Bel-Abbas in Algeria in 1893, discovered an "iteration of a rational function $f$ " with a "precise description of the set $J(f)$ of those $z$ in $\mathbf{C}$ for which the $n$th iterate $f^{n}(z)$ stays bounded as $n$ tends to infinity". That is, the outside boundary line goes to infinity as the inside bounded area stays finite. With the advent of computers, Benoit Mandelbrot was able to describe complex iterations such as this Julia Set as fractals. So although fractals are the patterns "by which nature organises clouds, rivers, mountains, many plants, tribal villages, our brains, lungs, and circulatory systems", Margaret Wheatley says, "we lacked a means for seeing them. Now that we can see them, there are some wonderful lessons to be learned." 6

The computer, then, opens up a new world. After billions of iterations of complex formulas are entered in a computer, a self-organising structure becomes visible, centring on a 'strange attractor'. Although fractals are everywhere, in coastlines and ferns and snowflakes, it is with the computer that they can be explored.

Other worlds opened up when the senses were extended as E. Atlee Jackson points out. Computer data acquisition and analyses expand scientific physical observables, in high energy physics, meteorology, medicine, industry, and astronomy. Satellite instruments extend observables in astronomy (with the Hubble telescope, COBE-cosmic background radiation). In neurology, extensions of observables come from EEG, PET, MRI, and MEG (magneto encephalography) instruments. For the microscopic world, there are electron and high-field intensity microscopes, and fluorescent microscopes. Information about complex structures comes from 
holographic-generated laser pulses, and optical fibres obtain information from many difficult areas, such as the interior of the functioning human body. ${ }^{7}$

Another gateway seems to be nothing more than a perspectival shift. A generation ago dentists did not use anaesthesia with children because it was thought unnecessary. Piaget characterised the first few weeks of infancy as "vegetative". Researchers exploring the world of the infant and the very newly born say they were not taken seriously for years. When they documented that babies less than an hour old would stick their tongue back at them, they were dismissed by people who could not accept the conclusions: that an infant, within an hour, knew that the researcher was a human being like her, that the researcher had a tongue and she had a tongue, and that she could respond by sticking out her tongue. How did the babies recognise that other people are "like me", that "we are like other people and they are like us"? ${ }^{8}$ As with any paradigm shift, one had to wait for one generation to pass on before the next could tackle these kinds of questions.

How did the new science discover that ants are intelligent? The idea of "swarm intelligence" apparently first surfaced in robot research. It also was found "in the field of semiotics to describe the kind of irrational buzz of ideas in the mind that underlies the communication of signs between two individuals". ${ }^{9}$ The Santa Fe Institute was saying "an ant colony can be thought of as a swarm whose individual agents are ants, a flock of birds is a swarm whose agents are birds, traffic is a swarm of cars, a crowd is a swarm of people, an immune system is a swarm of cells and molecules, and an economy is a swarm of economic agents". ${ }^{10}$ The use of 'swarm' as a new metaphor corresponds to a shift in perspective.

The shift in scientific perspectives over the past half-century has been from considering the ant as an individual without dignity, locked in a tyrannical web of conformity, to the ant as a simple but powerful information processor, to the metaphor of the individual ant as a component of a brain, to the modern view that the ant colony, composed of many collaborating individuals, is itself a powerful information processor. Contemporary ants are individuals as individuals, rather than parts of individuals, and their accomplishments are credited to their interindividual interactions. ${ }^{11}$

Clearly the idea that ants are intelligent and individuals is productive and offers many directions for further study, such as developing strategies to get airplanes to the gates more efficiently. The idea of the ant being "without dignity", it seems, was taught, just as is the idea that animals are different and inferior (but not everyone in every culture is so taught). That animals are creatures like humans, and therefore intelligent, is there from the beginning; we have to be taught to believe that animals are separate and different from us. ${ }^{12}$

With these gateways, modern scientists have found things that were invisible before. But in the Futūhăt are worlds whose landscapes are described in similar 
metaphors. One can describe both experiences with the same language. Ibn al- 'Arabī describes fractals without using any such word and without the idea of complex numbers. But his descriptions, as will be shown, are of fractals nevertheless. Ibn al- 'Arabī talks about tiny worlds, and about unimaginably large numbers and distances and times. He talks about things that are contradictions to the intellect but are nevertheless real. And he tells about his own daughter at 18 months answering a legal question, and recognising the approach of her father in a caravan coming to Mecca long before the adults could see him.

Although many science writers find wonder in the new science, not all, or even most, scientists see or speak of wonder in what they are studying. And even where there is wonder, something still seems to be missing. Recently a sea creature was reported frolicking around a camera cable 600 feet under the ice in Antarctica, and caught in a video which became a hit on YouTube. A similar story is told by Ibn al-'Arabī but with a difference. I juxtapose the two here.

Yet scientists were puzzled at what the food source would be for these critters. While some microbes can make their own food out of chemicals in the ocean, complex life like the amphipod can't, Kim said. So how do they survive? That's the key question, Kim said. "It's pretty amazing when you find a huge puzzle like that on a planet where we thought we know everything," Kim said. ${ }^{13}$

[From the Futūhāat 7:169:] It was said someone broke a hard dry rock and saw in the core of that rock a cavity in which was a larva in whose mouth was a green leaf she was eating. And it is related by an ancient prophet that the True One has under the earth a massive rock formation; in the core of this formation is an animal who has no outlet in the formation; and that the True One had made for him in there nourishment, and he praises True One, saying, "Praise to the one who has not forgotten me despite the distance of my place", meaning his distance from the site from which comes nourishments, not the distance of his place from the True One, because the relationship of the True One to his creation with respect to nearness (qurb) is one, but with respect to nearing (qarb), the relationship is various. So understand that. ${ }^{14}$

After looking at the obstacle to the gateways (the binding intellect), we explore five gateways that Ibn al- 'Arabī describes. There is the heart, which is the seat of God, in the divine saying, "The earth and the heavens are not vast enough for me, but the heart of my sincere creature is." There is the dream world, which Prophet Muhammad encouraged people to cultivate, and which he taught was one of 46 parts of prophecy. There is the 'creative imagination', the place where things are assembled and configured before they become and enter into the physical world. There is metaphor, which is finding the inner spirit attached to every outer reality. A metaphor for 'the metaphor' is the husk and the kernel, and the Qur'ān speaks 
of the people who understand the inner kernel, hidden by the outer husk. Finally, there is 'faith' or 'belief' in the unknown. One takes the word of one who has experienced the other worlds. If one does not have access to the other worlds, one can still be transformed by them. If one does not hear animals speak, one can accept that others do, and this may transform one's ideas about them as a resource to be exploited to seeing them as beings, who are as valuable as oneself, who teach and help us.

These worlds exist beyond the world constrained by the 'binding intellect'. In Arabic, the word for intellect ' $a q l$ is linguistically linked to the word for shackles or binding straps, 'uqūl.

\section{The Binding Intellect}

"This is one of the strangest things to me, that a human being follows his ratiocinations and ideas when they are as ephemeral as he is." Ibn al- 'Arabī goes on to say that even though the intellect depends on the senses, people follow it instead of "following one's Lord in what he has reported about himself in his book and on the tongue of his Messenger". ${ }^{15} \mathrm{He}$ then explains how some people move beyond the binding intellect, in this passage, which will open for us the subject of the gateway of the heart.

They do not accept the statement of the one who tells them, "There is after all another faculty behind you giving something different from what the faculty of ratiocination gives you, bestowed on the people of Allah from the angels and prophets and saints, articulated by the books sent down, so take from them these divine reports, as following the True One is better [...]."

They know there is after all another knowledge of Allah which does not come through the path of ratiocination, so they take up spiritual exercises, retreats, struggles with the self, severing associations, being alone, and sitting with Allah by emptying their place, and sanctifying the heart from tarnishes of ratiocinations, as it is connected to them. One takes this path from the prophets and the messengers, and one hears that the True One - his glory is beyond comprehension! - comes down to his creatures and asks about them. ${ }^{16}$ One knows the path to him in his direction is closer to him than the path of one's ratiocination, and especially if one is a person of faith. And one hears his word, "Who comes to me walking, I come to him running", and that one's heart is vast enough for the majesty and greatness of Allah. So one turns toward him in one's entirety and disconnects from everything which had been taken from these faculties. Upon this turning, Allah bestows generously on one from his light a knowledge of the divine [...].

In that is an indicative gesture to knowledge of Allah, with respect to witnessing, "as a reminder for the one who has a heart" [Qur'ān 50:37], and nothing else was mentioned, because the heart is known for fluctuating with the states ever, and it does not stay in 
one state; like that are the divine flashes. Whoever does not see the flashes with his heart, denies them, because the intellect binds, as do other faculties, except the heart, because it does not bind and is quick to fluctuate with every state. Because of this, the law-giver said, "The heart is between two of the fingers of the Merciful, who fluctuates it as he wills." It fluctuates with the fluctuations of the flashes, but the intellect is not like that. So the heart is the faculty behind the mountain of the intellect. If the True One had meant by 'heart' in this verse [Qur'ān 50:37] 'intellect', he would not have said, "to one who has a heart", because every human being has intellect, but not every human being is given this faculty which is behind the mountain of the intellect, called heart in this verse, so because of that, he said "to one who has a heart". (Futūhāt 1:435)

In the next passage, Ibn al- 'Arabī makes it clear that the intellect is not able to accept or reach knowledge of God. But even recognition of the limitations of the intellect is not something every intellect has access to.

The basis of the establishment of the shari 'ah in the world, and its purpose, is the amelioration of the world and knowledge about what is unknown about God, about what the intellect cannot accept; that is, the intellect cannot reach it independently, with respect to it the prophets spoke of it, peace be upon them, and the ones with intellects know by that that their intellects are deficient in knowledge of God, things which the messengers filled in for them. And I do not mean by ones with intellect the scholars today of 'wisdom', but instead I mean by the 'ones with intellect' the ones who are on their path, concentrating on their selves, doing spiritual exercises, and struggling with themselves, and who go into retreats and train for the rushes coming onto their hearts when they are polished by the upper world, inspired in the upper heavens; these are the ones I mean by 'ones with intellect'. The people who chatter and discourse and debate use their ratiocinations on linguistic roots originating among the ancients and are hidden from the matter from which these Men draw.

[...] The love of this world has taken possession over their hearts, and seeking standing and being in charge [...]. The mufti or faqīh of the religion of God with the least piety is in every respect in a better state than these. (Futūhāt 1:490)

The intellect binds, and therefore cannot independently gain knowledge about the divine. If the intellect binds itself successfully, it reaches the truth of Abū Bakr's famous statement, that "the inability to perceive is perception". Instead of making wild guesses and presumptuous statements, the one with correctly bounded intellect will halt with one's inability to perceive. In this way, the state of the non-intellectual with the least piety is better than that of the intellectuals who chatter and discourse and debate.

ICR 2.3 Produced and distributed by Pluto Journals ICR.plutojournals.org 


\section{The Heart}

\section{The Ever-Changing World Can be Seen by the Heart}

Ibn al-'Arabī has said that not everyone has access to the heart behind the mountain of the intellect. In this passage, he talks about the very, very rare being who can be called Muhammad̄̄, meaning, 'Muḥammadan'. He says,

[Rather, the Muhammadi] is at every breath, and at every time, and at every state with a form required by that breath or time or state. But one doesn't stay attached to it, because the divine forces differ in every time, so one is different with their differences, because he "is every moment doing something" [Qur'ān 55:29], so likewise with the Muhammadī. It is his word, "Verily in that is a reminder for the one who has a heart" [Qur'ān 50:37]. He did not say 'intellect', because the intellect binds. The heart qalb is named only because of its fluctuation taqallub during experiences and matters, constantly changing with every breath. (Futūhāt 7:113)

This idea of fluctuation connects with universal metaphors of being and becoming. Mechanistic science tends to focus on being and stability and solidity; new sciences look at fluidity, change, and emergence. Historically the concept of Islamic legal practice focused on 'becoming', where the role of the judge was to ascertain at that moment the best legal solution for the problem presented. Now, Islamic legal practice is biased toward 'being', and uses fixed, code books. The role of 'judge', meaning judging between different options, has almost disappeared. A similar situation applies in the United States, where mandatory sentencing removes the 'judging' part of the legal process. For Ibn al- 'Arabī, things change instantly and all the time. A person's behaviour is non-linear, and one can never be tied into a single, essential definition; one may be on a cusp, where one acts in a predictable manner until suddenly, one behaves completely differently. This flickering and fluctuation between states is familiar in the dream world.

\section{The Dream}

The flickering world of the heart and the dream is disturbing to the person who wants assurance and stability. The world when one is awake, one wants to believe, is full of solid and unchanging objects. If one wants to believe the solid, unchanging world is true, one will disparage the other, dream world. Ibn al-'Arabī describes the true value of the dream.

Because of this, the Messenger, when he got up in the morning when his Companions were with him asked them, "Has anyone of you seen a dream?" because it is prophecy, ${ }^{17}$ and he used to love to see it among his community. 
But the people today are in the utmost ignorance about this level which the Messenger was concerned for, asking every day about it. The ignorant in this time, when they hear something that happened while one was asleep, would not lift their heads, and they say, He wants to make judgments from his sleep! This is imagination and nothing but a dream! So they disdain the dream when one relies on it. This, all of it, is from his ignorance of its station and ignorance that while awake and being in a dream and in his sleep he is in a dream. He is like the one who dreams that he wakes from sleep while he is sleeping. It is his, peace be on him, word, "The people are asleep." How wondrous the prophetic reports! They explain the realities as they really are, and they give majesty to what the limited intellect disdains. It comes out only from the centre of the great; it is True. (Futūhāàt 4:14)

The idea that dreams provide scientists, for example, the visualisation of what they later discover in their study is well known, as for example Watson's dream of the entwining snakes representing the double helix and Einstein riding the beam of light. Some of the stories around scientific discovery may be apocryphal, but even so, dreams put in place what later is discovered or found. ${ }^{18}$ One kind of dream is about events that later come to pass. This dream corresponds with the imaginal realm where things are assembled and configured before entering the physical world.

\section{The Imaginal Realm}

Ibn al-'Arabī describes a 'date palm world':

When the True One made Adam, who is the first bodily human creature, and made him a root for human bodies to come into being, and there was extra fermented clay left over, he made from it the date palm. The Date Palm is the sister of Adam, and she is our aunt. Her epithet is aunt and she is likened to the sincere person. She has strange mysteries beyond the rest of the plants. After the creation of the date palm there was extra clay the size of a sesame seed, almost hidden. So the True One stretched this left-over into a planet of vast space.

When he made the throne and everything circling it, and the footstool, and the heavens and the earth, and everything under the ground, and the gardens, all of them, and the fire, in this planet, the entirety of it was like a ring tossed in one of the deserts of earth. With every breath the True One made worlds orbiting night and day, never flagging. The True One's immensity appears in this planet, and his power is magnified upon seeing the planet. Many things which are impossible to the intellect - which can reject them with sound intellectual proofs - are present in this planet and are displayed for the eyes of the wise who know the True One. In it they roam. The True One made one of the planet's worlds in our image. When the wise one sees it, one sees oneself in it. Ibn 'Abbās points to the likes of that in his story about this Ka'bah, that it is one of fourteen houses of

ICR 2.3 Produced and distributed by Pluto Journals ICR.plutojournals.org 
worship, and that in every one of the seven earths there is a creation like us, up to there being 'an Ibn 'Abbās like me there'. The ones who see through the veil confirm this story. (Futūhāàt 1:195)

Here are a quantum world and a multiverse in the imaginal realm, where opposites can be combined, where a body can be in two places, where an effect happens before its cause, and where the symbol of something becomes the thing itself.

[In the date palm world] everything which the intellect with its argumentations says is impossible, we find it in this world possible, and already having happened, and "God is Powerful over everything" [Qur'ān 2:20]. So we learn that the intellect is restricted, and that God is able to combine two opposites; create one body in two places; make a reaction an independent action and make it move to another place; and can make a symbol of something the thing itself. (Futūhāàt 1:201)

This list of things incomprehensible to the intellect reminds one of the debate on the Copenhagen interpretation of quantum mechanics, which seems to centre on whether the strangeness of this new world is epistemological or ontological. In other words, are the illogical events so because we are unable to understand them or are they really, ontologically, illogical? Physicists seem to accept the illogical as a fact and go about their work; but the question remains very important. Is the world strange only because we cannot see clearly enough?

It seems that the strangeness is ontological, with Ibn al-'Arabī, and that some people see through the stability and solidity of the world and find a moving, changing reality called, in this next passage, the Great River. This is a metaphor of the world as a Great River, on which the people with unveiled insight travel. The people who cannot see this great river try to build houses and imposing palaces on it, but the enterprise is doomed to failure, because they are building on a dam made of sticks.

They do not lay brick on brick or reed onto reed, and like this was the Messenger until he passed away to his Lord, not building at all any place for himself. The reason for that is that they see this world as a dam laid up with sticks against the Great River, while they are fording it and travelling on it. Have you seen anyone building a house on a dam of sticks? By God no, and especially when you know that the rains will come down, and that the river will become huge with floods from the rains, and that the dams will break, and that everything that is 'built on a dam' is a byword for destruction. If God pulled off the veils from the sight of the builders of this world, so they would see the buildings as dams and the river on which they were built as potent and perilous, they would not build what they build on it, such as imposing palaces. They do not have eyes to see that the world is a bridge of sticks over a Great River roaring. (Futūhāàt 1:322) 


\section{Metaphor}

'Metaphor', from the Greek, is meta-phorein, something I carry across. It is the process, here, of moving from the outside of something to its inside.

[...] because human beings may forget things they had recognised as they are; then one is reminded. It is his word, "But only those with the kernels remember" [Qur'ān 2:269] and his word, "so that they may remember, those with the kernels" [Qur'ān 38:29]. The kernel of something is its inner secret, its heart, and only its outer physical form hides it, which is to it like the husk over the kernel, a form hiding it with its own outerness. (Futūḥāt 7:356)

This problem of seeing the 'outerness' but missing what is inside corresponds to the lesson of the shadow play, which is saying something very important about outward forms, or shadows.

\section{They take their religion as play}

If you want to know the truth of what I am alluding to in this subject, consider the shadow play and its figures, and the vocalisation of these figures before the little children who are away from the veiling curtain drawn between them and the puppeteer of these figures and the vocaliser of them.

The matter is like that with forms of the world, and the people, most of them, are the little children whom we charge with obligation, so they know from where it is coming to them. The little children in the other setting are delighted and having fun, and the forgetful ones are taking it as 'mere amusement' and 'play'. But the ones who know read it metaphorically and recognise that God has set this up only as a parable, and because of that, in the beginning of the show a person comes out, called the Story Teller, and he starts a speech in which he says God is Great and he glorifies him. Then he speaks about each kind of puppet form that will come out after him from behind this curtain.

Then the gathering realises that God has set this up as a parable for his creatures, so they would read it metaphorically, and so they would know that the situation of the world, with God, is like these puppets with their being moved here and there, and that this curtain is a veil over a mystery of Predetermination put into effect for all creation. And despite all of this, the forgetful ones take it to be 'mere amusement' and 'play'. It is His statement: "Those who take their Religion as mere amusement and play" [Qur'ān 7:51]. Then the Story Teller disappears - he is in the place of the first to come into existence among us; it is Adam, peace be upon him - and when he disappears, his disappearance from us is to his Lord behind the curtain of his invisibility. God speaks the truth and $\mathrm{He}$ is the guide along the way. (Futūḥāt 5:100)

ICR 2.3 Produced and distributed by Pluto Journals ICR.plutojournals.org 


\section{The people congealed on the outward}

The 'forgetful ones' above miss the truth of the shadow play, and they miss the kernel-truth inside the husk. They are stuck at the "literal thinking" stage of small children. They are unable to move from the outward to the inward. Ibn al- 'Arabī explains, just before this following passage, that he will insh $\bar{a}^{\prime}$ Allāh write out all

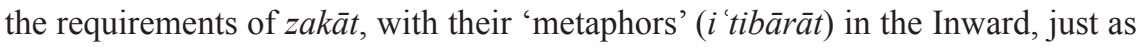
he did with the requirements of prayer (salāh), "where we combine the Outward and the Inward for a complete configuration." He says that "God has anchored to every physical form a spiritual meaning."

The divine spirit meaning of this form is the one we call the 'cross over' for the Inward, from he crosses over the arroyo when he traverses it. It is his word, "Verily in that is a cross over [ 'ibrah] for the one with sight" [Qur'ān 3:13], and "So cross over, you with sight" [Qur'ān 59:3], that is, go across what you see of forms with your seeing to what these forms give you of meaning and of the spirits in your inwardness, so perceive them with your sights, and bid and urge toward the metaphor. This subject has been forgotten by the 'ulamā', and especially the people who are congealed on the outward. They have nothing but dumbfoundedness at the metaphor. There is no difference between their intellects and the intellects of small children, and the former do not cross over at all from this outward form as God commands them to do. (Futūhāt 2:255)

\section{The fractal world}

The truth of a matter is not only hidden inside; it is also hidden in plain sight. Thus as with the fractal world, the truth of self-similarity may be lost on the observer. Ibn al- 'Arabī describes a treasure trove of particles. Each particle arrives from the treasure trove to you, the observer, and you two make an arc. The circumference defines a centrepoint, from which a line is drawn to the circumference and then outside, making another circumference, "half of it inside the first circumference and half of it outside it, to make Outward and Inward". The two new edges meet as they met when making the first circumference, "until it becomes its shape". Then another particle arrives in the new circle, "on and on without end. It is what protruded from the treasure troves which have no end of what is contained there. It is the New Creation which existence is upon ever and always, and some people, or most people, are in confusion about that, as he said, 'Rather, they are in confusion about the New Creation' [Qur'ān 50:15] with each breath.”

As the circles appear, whatever the number, and they keep on appearing, the first circle, which brought about these circles, starts to become hidden, not recognised, not perceived, because every circle approaching it or going away from it has its same form. So about each circle one can say it is seen, and it is not seen. This is the unseen in the seen. (Futūhăt 6:101) 
The new creations, here, are self-similar and scalable. The word Ibn al-'Arabī uses is amthall, which means likenesses or metaphors. The circumferences of each event are like in shape and contain particles that are likenesses to what came before. The view from very close is the same as the view from very far away. So the truth of each event is both seen and unseen.

\section{Faith}

"There is nothing but it glories him with his praise" [Qur'ān 17:44]; "thing" is undefined, and nothing glorifies unless it is alive, intelligent, knowledgeable about its glorification. It was related that the one who gives the call to prayer is attested to as far as his voice carries by anything wet [e.g., plants] and dry [e.g., rocks], and the revealed Laws and Prophecies are filled with this sort of thing. (Futūhāt 1:225)

Gateways to other worlds open up when one moves from the outside to the inside, and when, as with fractals, it is seen that an iteration can be said to be both the first and not the first. The perspectival shift suggested as opening other worlds in the new science may correspond to 'faith', where one operationalises the idea, for example above, that everything is alive. Once this idea takes hold, the world is seen differently.

\section{Spots on the Microscope}

With the explorations of these worlds, there is also an extensive body of literature over the centuries concerned with evaluating data, and warning about "faulty instrumentation". There are many "inrushes", and together with descriptions of them come evaluations and assessments. Dreams and inrushes may come from the divine, from the angelic realm, from the ego self, and from Satan. The list of activities that anyone on the path must undertake is long and includes spiritual exercises, struggles with the ego, going into retreat, fasting, and solitude, which are, it is assumed in traditional circles, supplements to one's own communal, religious life. The discoveries of someone whose microscope had spots on its glass or whose heart had not been polished are equally useless.

Ibn al-'Arabī uses a particular metaphor to warn against the havoc that the ego, one of the possible 'spot makers', creates when trying to navigate the path.

So this person who is walking on this path, if he does not really guard his lamp from the winds (ahwā', winds, ego) from blowing it out with its gusts, then the wind will gust against it fiercely and blow out his lamp and take away his light. (Futūhāa t4:473)

The lamp, here, is illumined by two sources of light, the light of shari 'ah and the light of insight, and the two are required. If one does not have the light of insight, one is blind to the light of the shari 'ah. 


\section{Principles}

\section{Change}

In the description of the Muhammadi the 'divine forces', the ahkām, apply to states, the $a h w \bar{a} l$, which change moment by moment. The intellect binds, and therefore cannot keep up with the changes, and so the heart is needed. Providing a comparison point for Ibn al- 'Arabī's ideas on the heart and change as they relate to understanding

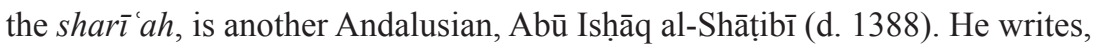

A second perspective is above this and finer, truly growing from the result of taqwā (mindfulness of God) mentioned before, in His word, "If you are mindful of God, He will provide for you a Criterion" [Qur'ān 8:29]. It may be expressed as "wisdom", alluded to by His word, "Wisdom is given to whom He wills, and who has been given wisdom has been given an immense Good" [Qur'ān 2:269]. Mālik said, "One of the 'matters' [from His word, 'Every moment He is upon some matter'; Qur'ān 55:29] of the children of Adam is that [one moment] they don't know, then [the next moment] they know. Haven't you heard the word of God, that 'If you are mindful of God, He will provide for you a Criterion'?"

One says too that wisdom is the angels brushing against the heart of the creature. And another says wisdom is light God emits onto the heart of the creature. And another says, there occurred in my heart wisdom of the understanding (fiqh) of the religion of God; a matter God put in the hearts from His kindness and excellence. Mālik disliked the writings on al- 'ilm, meaning something like [collections of] fatwās. So he was asked, "What should we do?" He said, "Keep being mindful, and keep trying to understand, until your hearts are illumined; then you won't need the writings." ${ }^{19}$

\section{Inner readiness}

The principle of directness is found in $i j t i h \bar{a} d$, the effort one makes to understand and apply the shari' $a h$. The person who does that is called a mujtahid. In this following passage, Ibn al-'Arabī addresses the widespread rejection of ijtihād in his time. He says,

The Law-giver has affirmed the decision of the mujtahid for himself and for whoever follows him, but the legal scholars of our time reject that and presume that that leads to playing with the religion, but that is the height of ignorance on their part. The matter is not, by God! as they presume, despite their affirming for themselves that they are not mujtahids and they have not reached the level of the mujtahid, and they do not transmit from their founders that they followed this method, so they give the lie to themselves in their statements that they are not, according to themselves, prepared to do ijtihād, but the thing they restrict the followers to do is only by ijtihãd! We take refuge in God from 
blindness and being forsaken! God only sent his messenger "as a mercy to the worlds" [Qur'ān 21:107], and what mercy is greater than the relief from this distress? (Futūhāat 2:24)

It is a telling irony that the 'gates of ijtihād' can only be closed by ijtihād.

The mujtahid has two rewards for the correct decision and one reward for the erroneous decision. Ibn al- 'Arabī traces being correct or erring to preparation, or readiness. "If he errs, the mujtahid errs only in readiness, as we spoke of it, and if he hits the mark in his readiness, the mujtahid never errs" (Futūhāat 5:399).

\section{Names and rulings}

The importance of getting the name right is a theme in Ibn al- Arabī's writings. In the $\operatorname{shar}^{-}$' $a h$, the decision $(h u k m)$ follows the named situation ( $\left.h \bar{a} l\right)$. As already seen, the situations change instantly and always, and therefore the heart, not the binding intellect, is required.

Mālik b. Anas, one of the leaders of the religion, was asked, What do you say about the Pig of the Ocean, is it a fish? He said, "It is unlawful [to eat]." He was asked, "But it is a fish of the ocean, and the ocean's beasts and carcasses are lawful." So he said, "You all have called it a pig, and Allah has made the pig unlawful [to eat]." So the ruling changed, according to Mālik, with the change of the name, and if they had asked him, "What do you say about the fish of the ocean or the beasts of the ocean?" The ruling would be according to the situation, and like that changing situations changes rulings. So the one person who is not in a dire situation eats a carcass and it is unlawful, but when that same person is in an emergency, he eats the carcass and it is lawful for him, so the ruling differed because the situation differed, but the thing is one and the same. (Futūhāt 5:232)

\section{Living}

In this passage, Ibn al-'Arabī contrasts a worldview that is static and dead with one that feeds directly into life.

Abū Yazīd al-Bistāmī, God be pleased with him, said, about this experience and its authenticity, speaking to superficial scholars, "You take your knowledge dead from the dead, but we take our knowledge from the Living who does not die, and, ones like us say. My heart spoke a hadith to me from my Lord, but you say, 'So and so gave a hadith, but where is he?' They say, 'He is dead, but it came from so and so.' Where is he? They say, 'He is dead.'" And Shaykh Abū Madyān, God be kind to him, when he was told, "So and so told so and so from so and so," he said, "We don't want to eat jerky! Bring to us some fresh meat to raise the spirits!" (Futūḥāt 1:423)

The permission to engage this living law is special to "this community", in the law of "who makes a practice (sunnah) which is fine". Ibn al- 'Arabī says, 
This principle is special to this community, and I mean by 'principle' calling it a sunnah, given as an honour to this community [...].

The difference between 'following' and 'innovating' is understandable, and because of this, the Lawgiver inclines to calling it sunnah and does not call it bid 'ah (innovation). Innovation is bringing out something whose origin has no similar model, and because of this, God said about himself, "Creator (al-bādi ') of the heavens and the earth" [Qur'ān $2: 117]$, that is, the one who brought it into existence without any previous model. If human beings today make a law that has no basis in the Law, then that would be an innovation, and it would not be acceptable for us take it. The Lawgiver turns from the word 'innovation' to the word sunnah, as the sunnah is set by the sharī ah. (Futūhāàt 1:497)

\section{Easefulness}

With the principle of ease, there is the principle of fewer laws. Ibn al- 'Arabī says, "it is the increase in knowledge we are told to pursue, not 'ilm (knowledge) of taklif [things we must do], because the less in it is what is sought by the prophets, on whom be peace, and because of this, the Messenger said, 'Leave off me what I leave off of you"' (Futūhāt 3:175).

Thus, the principle of ease which lies in accepting differences in legal rulings. In this passage, Ibn al-'Arabī has just explained how to understand the seeming contradiction between prayer times being distinct or overlapping. He says,

It is appropriate in this issue and its likes that there would not appear differences, but God has made this difference a mercy to his creatures and a spreading out of what he has told them to do in worship. But the legal scholars of our times have fenced in and constricted for the people who are following the 'ulamā' what the Law-giver has spread out for them. So they say to the follower, if he is of the Hanafi school, don't look for an allowance from the Shäfi 'is for what happened to you, and like that for every one of them. This is one of the greatest disasters of the religion and of hardships, as God says [Qur'ān 22:78], "We have not made for you in the religion any hardship." (Futūhāa 2:24)

\section{Avatar}

If the 'revealed laws and prophecies' are filled with stories of a world alive, intelligent, as Ibn al-'Arabī says, then even today stories of such a world are also to be found, in popular culture, for instance in the recent movie Avatar. In this movie, Jack Sully moves through many 'worlds' until he reaches his ultimate, or at least most real, world, which he sees at the very moment his eyes open and the movie ends. He has a twin, whose death opens up the opportunity for him to become an 'avatar' (from root tr meaning 'cross over' and ava meaning 'down', with a source text in the Gita 4:8). Sully then sleeps for six years in space, waking up on Pandora. 
There, he enters into another coffin-like machine where his self is transferred to another, Pandoran body. Along the way, he receives initiation into the tribe, which for him is the death of his earthly aspirations and the birth of his new affiliation with the tribe. Finally, he must shake off once and for all his earthly body to live fully as a new being in the world he opens his eyes to as the movie ends.

It is interesting how easily the metaphors flow in this movie about sleep and dreams, this body and another body, death as entering a new life and new world. The movie series Star Wars explicitly adopted metaphors from Sufism, such as

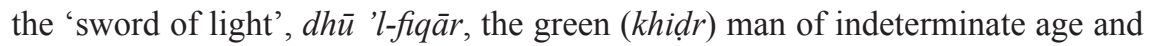
vast wisdom (Yoda), and a concept of chivalry (futuwwah) different from that of medieval Europe. Both tell stories that live beyond the mechanistic worldview of the last three centuries.

\section{Conclusions and Recommendations}

Are either of the two parties ready to converse in the language spoken above? Scientists respond in widely different ways: one, utterly dismissive of religions and spirituality, another excited about finding human meaning in the new discoveries, and another, unaware that his own religious tradition could speak to his research and studies in the new science.

- With people coming from religious backgrounds, one has come to the conclusion that 'religion' is irrelevant to the new science and world today and another is very concerned that if 'religion' gives any room to innovation, change, and process, it will be destroyed.

- The signs of the divine are in every place and time, and the new science has simply opened up another set of signs, for those who can read them.

- If religion-as-it-is-practised does not respond to and find signs in every place and time, it stagnates. Without a living stream of signs in a religion as it is practised, people, perhaps especially the intelligent youth, look elsewhere for sustenance. Islam, expected by Muslims to be a totality, becomes bifurcated into 'religion' over here, meaning ritual and culture, and 'life' over here.

This language seems to pool around 'life' instead of 'religion'. And is this not what the twentieth-century Islamic 'revivalists' said, that Sufis 'weakened' the Muslim ummah because they encouraged a spirituality that was individual and private? ${ }^{20}$ And that to 'revive' Islam and its dominance in the world Muslims had to fight for an 'Islamic state', advancing an outward religion and attacking inward spirituality? Does this mean that a 'new' language would affirm the co-existence of private spirituality with public religiosity? How many people in pious societies 
see themselves privately or anonymously as secular or unaffiliated with official religion and public religious practice?

- Or does this language speak of a universal Islam, one which is both seen and unseen, which draws its sustenance from signs everywhere and always, which is relevant to the pressing concerns of globalisation, pluralism, environment, and ever increasing militarisation? I think it does, and I think this language supports civilisational renewal and especially the process of gaining a view of the coherency of Islam and the higher goals of the Law.

\section{Notes}

1. Hakim Bey, "Quantum Mechanics and Chaos Theory: Anarchist Meditations on N. Herbert's Quantum Reality: Beyond the New Physics" (1991), available online at http://hermetic.com/bey/ quantum.html (accessed on 2 December 2010).

2. Robert D. Crane, "Mission of Muslims in America: A Grand Strategy to Marginalise Extremists Part II", theamericanmuslim.org, 18 July 2007, available online at http://www.theamericanmuslim. org/tam.php/features/articles/mission_of_muslims_in_america_a_grand_strategy_to_marginalize_ extremists_pa/ (accessed on 2 December 2010).

3. Vincent J. Cornell, "Practical Sufism", Sophia 15, no. 2 (2010), 106.

4. The political dimension, however, cannot be suspended or ignored. Muslim societies politically are not able to contend with science and technology dominated by corporations and governments wed to corporations. My hope is that there is some space where communication can take place, with scientists who are aware of this political dimension.

5. See http://www-groups.dcs.st-and.ac.uk/ history/Biographies/Julia.html (accessed on 2 December 2010).

6. Margaret Wheatley, Leadership and the New Science (San Francisco: Berrett-Koehler Publishers, 2006), 124.

7. E. Atlee Jackson, "The Second Metamorphosis of Science: A Second View", Santa Fe Institute Foundational Papers (1996), available online at http://www.santafe.edu/media/workingpapers/9606-039.pdf (accessed on 2 December 2010), 12.

8. Alison Gopnik, Andrew N. Meltzoff, and Patricia K. Kuhl, The Scientist in the Crib: Minds, Brains, and How Children Learn (New York: William Morrow, 1999), 30.

9. James Kennedy, Russell C. Eberhart, and Yuhui Shi, Swarm Intelligence (San Diego CA: Morgan Kaufmann, 2001), 102.

10. Ibid.

11. Ibid., 103.

12. "Kids Understand the Relationship between Humans and Other Animals", 17 May 2010, available online at http://www.physorg.com/news193336854.html (accessed on 2 December 2010).

13. Filed by Seth Borenstein on 15 March 2004 with Associated Press, available online at http:// www.huffingtonpost.com/2010/03/15/nasa-finds-shrimp-like-cr_n_499155.html (accessed on 2 December 2010).

14. Citations from the Futūhāt are from the edition published by Dār al-Kutub al- 'Ilmiyyah, Beirut, 1999. A note on translation: 'True One' is sometimes used as a translation for al-Haqq, 'creature' for 'abd, 'sincere' for mu'min, and 'men' for rijäl, which in Sufi usage is not gender-specific. While names are capitalised, pronouns for the divine are not.

15. Futūhāàt 1:435. 
16. For example, Șahịh Muslim, Book 4, hadīth no. 1,656: "The Messenger said, 'Our Lord comes down every night to the sky of this world and says, \{Is there anyone beseeching me that I may answer? Is there anyone asking something from me that I may provide it? Is there anyone seeking forgiveness that I may forgive?\}'."

17. Șahīh Muslim, Book 29, hadīth no. 5,622: "The dream of a sincere person is one of forty-six parts of prophecy."

18. See for example Andrea Rock, The Mind at Night: The New Science of How and Why We Dream (New York: Basic Books, 2004) and Deirdre Barrett, The Committee of Sleep: How Artists, Scientists, and Athletes Use Dreams for Creative Problem-Solving (New York: Crown, 2001.)

19. Abū Isḥāq al-Shātịīi, Al-Muwāfaqāt fì ușūl al-sharī ah (Cairo: Dār al-Ḥadīth, 2006), 3:367.

20. A description of these criticisms and their refutation is found in Cornell, "Practical Sufism". 